\title{
(Research Article) \\ Influence of Binder Type and Additives on Permanent Deformation of Asphalt Concrete
}

\author{
S. I. Sarsam * \\ *Director, Sarsam and Associates Consult Bureau (SACB), Baghdad-IRAQ \\ Formerly at Department of Civil Engineering, University of Baghdad, Baghdad, IRAQ
}

\begin{abstract}
Asphalt concrete mixture usually suffer permanent deformation under load repetitions and hot climate condition. Research work is going on globally to implement additives in the binder production process or through the preparation of asphalt concrete mixture. In the present investigation, an attempt has been made for the inclusion of three types of additives namely (crumb rubber powder, fumed silica, and Phosphogypsum) into the asphalt cement binder using two types of penetration grade asphalt cement (40-50) and (60-70). Asphalt concrete mixtures were prepared, Marshall specimens have been constructed and tested under repeated indirect tensile stresses with the aid of Pneumatic Repeated Load System PRLS. The influence of such additives on the permanent deformation at $40{ }^{\circ} \mathrm{C}$ environment was monitored through continuous video capture. It was concluded that the temperature susceptibility of the binder in terms of PI increases after digestion with fumed silica and Phosphogypsum while it decreases after the addition of crumb rubber. The rate of deformation decreases by (25 and 30) \% by implication of rubber and Phosphogypsum additives respectively for (40-50) grade binder. However, the rate of deformation declines by (15, 3 and 21) \% for (60-70) binder by implication of rubber, fumed silica, and Phosphogypsum additives respectively.
\end{abstract}

Keywords: : Deformation, Asphalt cement, Additives, Repeated load, Tensile stress, Fumed silica, Crumb rubber.

\section{Introduction}

Binder additives are implemented to enhance the engineering and rheological properties of asphalt which influence the performance and service life of the binder greatly. Asphalt cement contains two main groups namely asphaltenes and maltenes, where maltenes can be further categorized as saturates, aromatics and resins. The ratio between asphaltenes and maltenes influence the mechanical properties of the binder and thus the performance of the flexible pavement as reported by Esmaei et al., [1]. Binder modification has been considered recently including powder and nanomaterial as stated by Korayem et al., [2]. The micro and nano scaled materials (such as silica fume) have been found to improve the properties of the binder due to high surface area as mentioned by Khodary, [3]. Polymer modified asphalt has been found to improve properties like fatigue, temperature susceptibility and permanent deformation. The polymers used for modification are styrene-butadiene-styrene (SBS) copolymer, latex, ethylene-vinyl acetate (EVA), polyethylene, polypropylene etc. as mentioned by Aflaki and Tabatabaee, [4]. As stated by Silva et al., [5], three types of

*Corresponding Author: e-mail:

saadisasarsam@coeng.uobaghdad.edu.iq

ISSN 2320-7590

(C) 2020 Darshan Institute of Engg. \& Tech., All rights reserved. compatibility between polymer and asphalt occur, the first is heterogenous mixture where asphalt cement and polymer are incompatible and are separated into two phases, the resulting mixture is not a polymer modified asphalt. The second is homogenous mixture where polymer and asphalt are compatible, and the mixture is stable as the asphalt oil fraction totally solvates the polymer, but the desire enhancement is not obtained. The third is a microheterogeneous mixture that is made up of two distinct finely interlocked phases. The polymer phase is swollen by absorbing the asphalt aromatic oil fraction. This is a mixture that offers better mechanical properties and characteristics when compared with unmodified asphalt. Deepa et al., [6] concluded that waste plastic can be used at elevated service temperatures. The composite also shows better elastic recovery which can help sustain the low temperature cracks. Previous study by Albayati, [7], found that asphalt concretes with added hydrated lime showed improved durability, including the ability to resist permanent deformation, a reduction of hardening age, and increase of flexural stiffness at moderate and high temperatures. Al-Tameemi et al., [8] concluded that at low testing temperature of $20^{\circ} \mathrm{C}$, the addition of $2.5 \%$ of hydrated lime shows a limited effect on the enhancement of the resistance to permanent deformation. However, at relatively high temperatures $(40 \text { and } 60)^{\circ} \mathrm{C}$, the effect of adding hydrated lime becomes more significant, and 
can balance between rutting susceptibility, resistance to rutting, and workability. Mahdi and Sarsam, [9] investigated the effect of two types of additives (Styrene-ButadieneRubber SBR and carbon black) on the performance of recycled asphalt concrete mixture. It was concluded that the Resilient modulus at (0.138 and 0.206) $\mathrm{MPa}$ stress level decreases by (14, 22 and 8$) \%$ and $(22,34$ and 11) for reclaimed and recycle mixtures with (carbon black-asphalt and SBR-asphalt) respectively when compared with that at 0.068 MPa. However, the permanent deformation for recycled mixtures with (carbon black-asphalt and SBRasphalt) increased by $(65.9,4.54) \%,(146.6,27.2) \%$ and $(79$, $5.5) \%$ at level of stresses $(0.068,0.138$ and 0.206$) \mathrm{MPa}$ respectively when compared to reclaimed mixture. Sarsam and Jasim, [10] investigated the impact of polymer additives (SBS, LDPE, and rubber) on the crack healing ability of asphalt concrete through its influence on permanent deformation under repeated compressive stress. It was concluded that polymer additives have a positive impact on microcrack healing process. For pure asphalt, SBS, LDPE, and rubber modified mixes, the permanent deformation at optimum asphalt content decreases by a range of (29-67), (63-73), (14-53) and (16-18) \% after one and two healing cycles respectively as compared with control mix. A study by Ahmad et al.,[11] has chosen waste crumb rubber and Bakelite to study the mechanical properties of asphalt concrete by addition ratio of $4.0 \%, 8.0 \%, 12.0 \%, 16.0 \%$ and $20.0 \%$. Marshall mixture were designed and tested for density, Marshall stability, flow, air voids and stiffness properties for the control, crumb rubber and Bakelite samples. The test result shows that addition of crumb rubber and Bakelite by $12 \%$ significantly improve the properties of asphalt mixture almost double for Marshall stability when compared to the control sample, higher stiffness shows strong resistance against rutting and permanent deformation. The study concluded that crumb rubber and Bakelite have potential to enhance the mechanical properties. Crumb rubber modifier (CRM) is believed to be a good alternative polymer for improving binder performance properties in HMA as stated by Ahmad and Ayob, [12].

The aim of the present investigation is to assess the influence of crumb rubber, fumed silica, and Phosphogypsum on the rheological properties of asphalt cement and its influence on permanent deformation under repeated tensile stresses.

\section{Materials and Methods}

The materials implemented in this investigation are aggregates, mineral filler, additives and two grades of asphalt cement. The properties of these materials were evaluated using routine types of test.

2.1 Asphalt Cement: Two penetration grade types of asphalt cement were considered, (40-50) and (60-70). Both types are obtained from the Dourah refinery. The asphalt cement properties based on the conventional penetration grading system are illustrated in Table 1. The optimum asphalt content was $5 \%$ by weight of total mixture.

Table 1. Physical Properties of Asphalt Cement

\begin{tabular}{|l|l|l|c|}
\hline Property & $\begin{array}{l}\text { ASTM, [13] } \\
\text { Designation }\end{array}$ & $\begin{array}{l}\text { Asphalt } \\
\text { cement } \\
\text { grade(40-50) }\end{array}$ & $\begin{array}{l}\text { Asphalt } \\
\text { cement } \\
\text { grade(60-70) }\end{array}$ \\
\hline $\begin{array}{l}\text { Penetration } \\
\text { at 25 }{ }^{\circ} \text { C, } \\
100 \quad \text { gm,5 } \\
\text { sec, } \\
(0.1 \mathrm{~mm})\end{array}$ & ASTM D-5 & 44 & 66 \\
\hline $\begin{array}{l}\text { Softening } \\
\text { Point, }{ }^{\circ} \mathrm{C}\end{array}$ & ASTM D-36 & 50 & 48 \\
\hline $\begin{array}{l}\text { Ductility at } \\
25 \text { C }, \\
5 \mathrm{~cm} / \text { min, } \\
(\mathrm{cm})\end{array}$ & ASTM D-113 & +100 & +100 \\
\hline
\end{tabular}

2.2 Coarse and Fine Aggregates: The crushed coarse and fine aggregates used in this work were obtained from AL-Nibaie quarry. Such aggregates are widely used in local asphalt paving. The aggregates were separated to different sizes by sieving, oven dried, then recombined in the proper proportions to meet the wearing coarse gradation as required by SCRB R/9, [14] specification. The wearing coarse layer was selected because this layer is always in direct contact with traffic loadings and variations in environmental conditions. Routine tests were performed on the aggregates to evaluate their physical Properties. Table 2 summarizes the physical properties of aggregates.

Table 2. Physical Properties of Aggregates

\begin{tabular}{|l|l|l|l|}
\hline Property & $\begin{array}{l}\text { ASTM, [13] } \\
\text { Designation }\end{array}$ & $\begin{array}{l}\text { Coarse } \\
\text { aggregates }\end{array}$ & $\begin{array}{l}\text { Fine } \\
\text { aggregates }\end{array}$ \\
\hline $\begin{array}{l}\text { Bulk specific } \\
\text { gravity }\end{array}$ & C-127, C-128 & 2.610 & 2.640 \\
\hline $\begin{array}{l}\% \text { Water } \\
\text { absorption }\end{array}$ & C-127, C-128 & 0.448 & 0.720 \\
\hline $\begin{array}{l}\text { Los Angeles } \\
\text { Abrasion \% }\end{array}$ & C-131 & $22.2 \%$ & --------- \\
\hline
\end{tabular}

The selected wearing course gradation with specification limits are presented in Table 3.

Table 3. Implemented Gradation of Wearing Course

\begin{tabular}{|c|c|c|c|c|c|c|c|}
\hline $\begin{array}{l}\text { Sieve size } \\
(\mathrm{mm})\end{array}$ & 19 & 12.5 & 9.5 & 4.75 & 2.36 & 0.3 & 0.075 \\
\hline $\begin{array}{l}\% \text { passing } \\
\text { by weight }\end{array}$ & 100 & 95 & 83 & 59 & 43 & 13 & 7 \\
\hline $\begin{array}{l}\text { SCRB, } \\
\text { [14] limits } \\
\text { for } \\
\text { wearing } \\
\text { coarse }\end{array}$ & 100 & $\begin{array}{l}90- \\
100\end{array}$ & $\begin{array}{l}76- \\
90\end{array}$ & $\begin{array}{l}44- \\
74\end{array}$ & $\begin{array}{l}25- \\
58\end{array}$ & $\begin{array}{l}5- \\
21\end{array}$ & $4-10$ \\
\hline
\end{tabular}


2.3 Mineral Filler: The mineral filler used in this work is limestone dust, it was obtained from lime factory in Karbala governorate. The physical properties of the filler are presented in Table 4.

Table 4. Physical Properties of Mineral Filler

\begin{tabular}{|l|l|}
\hline Property & Test results \\
\hline Specific gravity & 2.794 \\
\hline Passing sieve No.200 $(0.075 \mathrm{~mm})$ & $94 \%$ \\
\hline
\end{tabular}

2.4 Crumb Rubber: Crumb rubber was brought from tires factory in AL-Najaf governorate. This type of crumb rubber powder is recycled from used tires. The specific surface area of crumb rubber powder is $80 \mathrm{~m}^{2} / \mathrm{kg}$ while the specific gravity is 1.130 . Table 5 show the grain sizes distribution of crumb rubber. Figure 1. present the sample of crumb rubber used.

Table 5. Grain sizes distribution of crumb rubber

\begin{tabular}{|l|c|c|c|c|c|c|c|}
\hline $\begin{array}{l}\text { Sieves } \\
\text { Size }(\mathrm{mm})\end{array}$ & 4.75 & 2.36 & 2.1 & 1.18 & 0.6 & 0.3 & 0.075 \\
\hline $\begin{array}{l}\text { \% Finer by } \\
\text { Weight }\end{array}$ & 100 & 100 & 97.4 & 52 & 20 & 8 & 0 \\
\hline
\end{tabular}

2.5 Fumed silica: Fumed silica is supplied as a white, fluffy powder. The Chemical composition is presented in Table 6. The physical properties are given in Table 7, while Figure 1 present the Fumed silica sample used.

Table 6. Chemical Components of Fumed silica

\begin{tabular}{|c|c|}
\hline Chemical component & Percentage \\
\hline $\mathrm{SiO}_{2}$ & 99.1 \\
\hline $\mathrm{Fe}_{2} \mathrm{O}_{3}$ & $35 \mathrm{ppm}$ \\
\hline $\mathrm{AL}_{2} \mathrm{O}_{3}$ & $<0.035$ \\
\hline $\mathrm{TiO}_{2}$ & $<0.006$ \\
\hline $\mathrm{CaO}$ & 0.03 \\
\hline $\mathrm{MgO}$ & $52 \mathrm{ppm}$ \\
\hline $\mathrm{SO}_{3}$ & $<0.07$ \\
\hline L.O.I. & $0.7 \%$ \\
\hline
\end{tabular}

Table 7. Physical properties of Fumed Silica as Supplied by Weaker Company

\begin{tabular}{|c|c|}
\hline Physical Properties & Test result limits \\
\hline Surface area $\mathrm{m}^{2} / \mathrm{kg}$ & 4500 \\
\hline Density $\mathrm{kg} / \mathrm{m}^{3}$ & 170 \\
\hline $\begin{array}{c}\text { Loss of weight } \% \text { when drying at } \\
1000^{\circ} \mathrm{C} \text { for } 2 \text { hours }\end{array}$ & $<2$ \\
\hline $\begin{array}{c}\text { Loss of weight } \% \text { when drying at } \\
105^{\circ} \mathrm{C} \text { for } 2 \text { hours }\end{array}$ & $<1.5$ \\
\hline PH & 4.3 \\
\hline$\%$ Retained on $40 \mu \mathrm{m}$ sieve & $<0.04$ \\
\hline Moisture \% & 0.82 \\
\hline
\end{tabular}

2.6 Phosphogypsum: Phosphogypsum is industrial residual waste in a powder form resulting from the production of phosphate. The Phosphogypsum has a specific gravity of 2.35, Free Moisture $8-18 \%$ and it is passing sieve No. 50 Sieve. The specific surface area of Phosphogypsum powder is $500 \mathrm{~m}^{2} / \mathrm{kg}$. Table 8 shows the Chemical components of Phosphogypsum, while Figure 1 present the Phosphogypsum sample used.

Table 8. Chemical Components of Phosphogypsum

\begin{tabular}{|c|c|}
\hline Chemical component & Percentage \\
\hline $\mathrm{SiO}_{2}$ & 0.84 \\
\hline $\mathrm{Na}_{2} \mathrm{O}$ & 0.212 \\
\hline $\mathrm{P}_{2} \mathrm{O}_{3}$ & 0.90 \\
\hline $\mathrm{F}$ & 0.642 \\
\hline $\mathrm{CaO}$ & 33.06 \\
\hline $\mathrm{MgO}$ & 0.56 \\
\hline $\mathrm{SO}_{3}$ & 44.18 \\
\hline L.O.I. & 18.11 \\
\hline
\end{tabular}
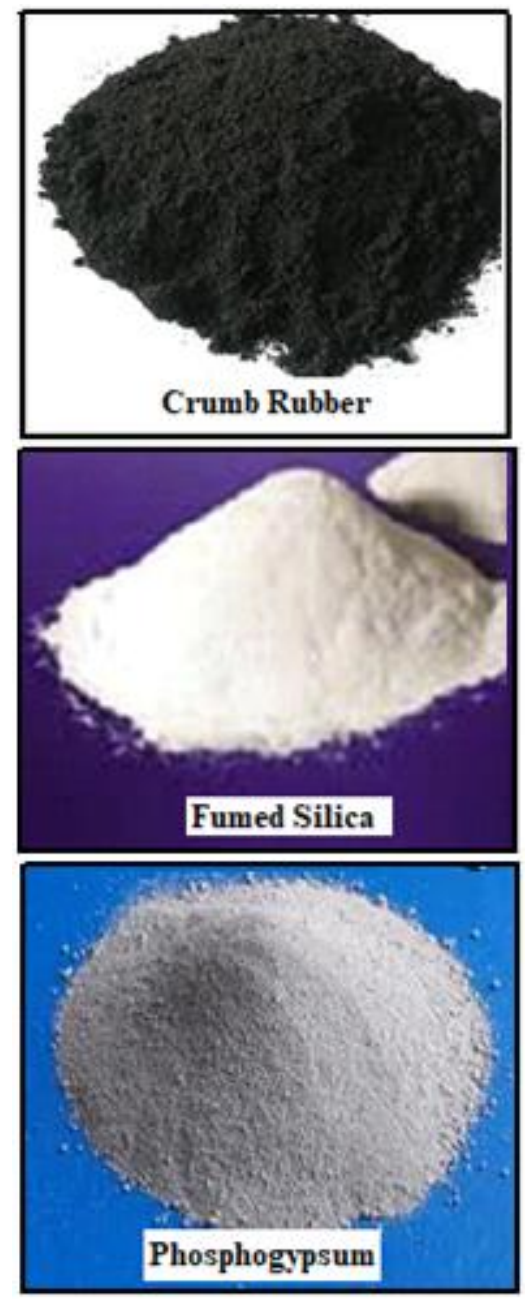

Figure 1. The Implemented Additives 


\section{Preparation of Modified Asphalt Cement}

3.1 Rubber-Asphalt Cement Mix: Asphalt cement was heated to a temperature of $160^{\circ} \mathrm{C}$ for asphalt cement $(40$ 50 ), and $150^{\circ} \mathrm{C}$ for asphalt cement (60-70), and then rubber powder was added and mixed thoroughly using manual stirring on the hot plate for 60 minutes as a constant blending time. Various percentages of crumb rubber have been tried with different mixing periods and the optimum crumb rubber content was selected based on the changes in physical and rheological properties of the blend. The optimum percentages of crumb rubber were (7 and 5) \% for asphalt cement of penetration grade (60-70) and (40-50) respectively which have been selected and implemented in this investigation. Details of the selection process could be found in Sarsam and Lafta, [15].

\subsection{Fumed Silica-Asphalt Cement Mix: Asphalt} cement was heated to a temperature of $160^{\circ} \mathrm{C}$ for asphalt cement (40-50), and $150^{\circ} \mathrm{C}$ for asphalt cement (60-70), and then fumed silica was added and mixed using manual stirring on the hot plate for 45 minutes as a constant blending time. Various percentage of the Fumed silica by weight of asphalt cement (40-50) and (60-70) have been tried. The optimum fumed silica content was selected based on the changes in physical and rheological properties of the blend. The optimum percentages of fumed silica were ( 3 and 1$) \%$ for asphalt cement of penetration grade (60-70) and (40-50) respectively which have been selected and implemented in this investigation. Details of the selection process could be found in Sarsam, [16].

3.3 Phosphogypsum-Asphalt Cement Mix: Asphalt cement has been heated to a temperature of $160^{\circ} \mathrm{C}$ for asphalt cement (40-50), and $150^{\circ} \mathrm{C}$ for asphalt cement (60-70), and then phospho-gypsum was added and mixed using manual stirring on the hot plate for 30 minutes as a constant blending time. Various percentage of the Phospho-gypsum by weight of asphalt cement (40-50) and (60-70) have been tried. The optimum Phosphogypsum content was selected based on the changes in physical and rheological properties of the blend. The optimum percentages of Phosphogypsum were (3 and 1) $\%$ for asphalt cement of penetration grade (60-70) and (40-50) respectively which have been selected and implemented in this investigation. Details of the selection process could be found in Sarsam and Lafta, [17].

3.4 Preparation of asphalt concrete specimens: Coarse and fine aggregates were combined with mineral filler to meet the specified gradation. The combined aggregate mixture was heated to $160{ }^{\circ} \mathrm{C}$ before mixing with asphalt cement, while the asphalt cement or modified binder was heated to $150^{\circ} \mathrm{C}$. Then, the required amount of asphalt cement was added to the heated aggregate and mixed thoroughly using mechanical mixer for two minutes until all aggregate particles were coated with thin film of asphalt cement. Marshall specimens were prepared in accordance with ASTM D1559, [13] using
75 blows of Marshall hammer on each face of the specimen. The optimum asphalt content was determined to be $5 \%$ by weight of aggregates. The prepared Marshall specimens were subjected to the repeated indirect tensile stresses in the pneumatic repeated load system PRLS at $40^{\circ} \mathrm{C}$ environment. Specimens were tested in duplicate, and the average value was considered for analysis. Details of obtaining the optimum asphalt content and the strength properties of asphalt concrete could be found in Sarsam and Al-Delfi, [18].

3.5 Testing of Asphalt Concrete Specimens under Repeated Indirect Tensile Stresses (ITS): The pneumatic repeated load system (PRLS) was implemented. Before the test, specimens were stored in the chamber of the testing machine at room temperature $40 \pm 1^{\circ} \mathrm{C}$. The asphalt concrete specimens were subjected to repeated indirect tensile stresses (ITS) for 1000 load repetitions at $40^{\circ} \mathrm{C}$. Such test conditions were suggested by several authors, Dalhat et al., [19] and Roque et al., [20]. Loading was applied on the specimen, which was centered on the vertical diametrical plane through two parallel loading strips, $12.7 \mathrm{~mm}$ wide. The load assembly applies indirect tensile stress on the specimen in the form of rectangular wave with constant loading frequency of $60 \mathrm{cycles} / \mathrm{min}$. The applied stress level was $0.138 \mathrm{MPa}$. A heavier sine pulse of $0.1 \mathrm{sec}$ load duration and $0.9 \mathrm{sec}$ rest period was applied over test duration period. The test was continued for 1000 load repetitions, upon completion of test, the recording was terminated. The deformation of the specimens under repeated indirect tensile stresses and the number of load repetitions were captured using video camera attached to the (PRLS). The average of two samples of each asphalt cement type was calculated and considered for analysis as recommended by Sarsam, [21]. Figure 2 demonstrates the PRLS system with ITS setup.

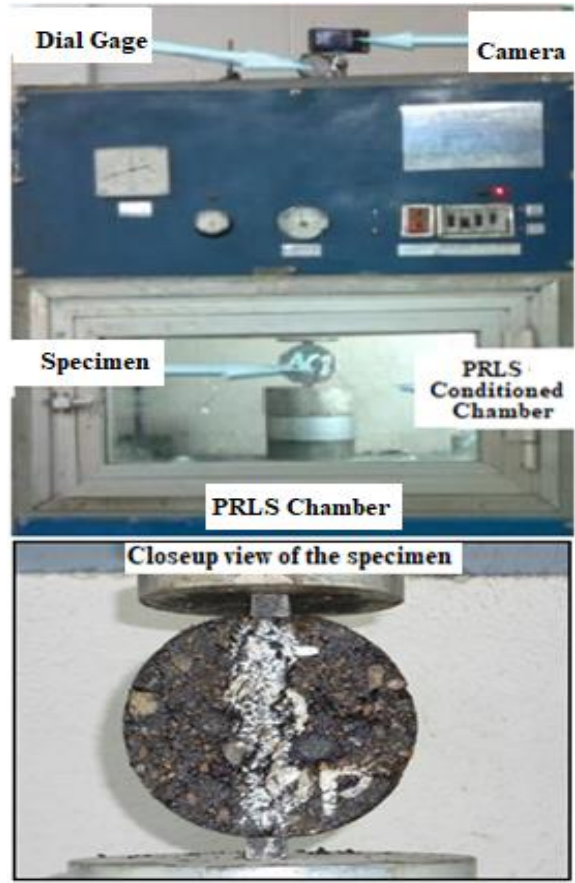

Figure 2. The Pneumatic Repeated Load System PRLS 


\section{Results and Discussion}

4.1 Influence of Additives on Temperature Susceptibility Parameters of the Binder: The temperature susceptibility parameters of the blended asphalt cement with various additives were obtained using the shell nomograph and the mathematical models presented in Yoder and Witczak, [22]; Shell, [23] and Tayebali et al., [24]. Temperature susceptibility is the rate at which the consistency of asphalt cement changes with a change in temperature. The temperature susceptibility is verified in terms of penetration index $(\mathrm{PI})$, penetration viscosity number $(\mathrm{PVN})$, and stiffness modulus (SM). Table 9 exhibit the temperature susceptibility parameters of the binders.

Table 9. Temperature Susceptibility Parameters

\begin{tabular}{|l|l|l|l|}
\hline \multicolumn{4}{|c|}{ Asphalt cement grade (60-70) } \\
\hline Type & PI & PVN & $\begin{array}{l}\text { Stiffness } \\
\text { Modulus } \\
\left(\mathrm{KN} / \mathrm{m}^{2}\right)\end{array}$ \\
\hline Control & -1.474 & 6.09 & 300 \\
\hline 7\% Rubber & -1.094 & 5.75 & 400 \\
\hline 3\% Fumed Silica & -2.466 & 6.07 & 100 \\
\hline 3\%Phosphogypsum & -1.928 & 6.09 & 250 \\
\hline \multicolumn{4}{|c|}{ Asphalt cement grade (40-50) } \\
\hline Type PI & PVN & $\begin{array}{l}\text { Stiffness } \\
\text { Modulus } \\
\left(\mathrm{KN} / \mathrm{m}^{2}\right)\end{array}$ \\
\hline \multicolumn{4}{|c|}{} \\
\hline Control & PI & 6.22 & 500 \\
\hline 5\% Rubber & -1.055 & 600 \\
\hline 1\% Fumed Silica & +0.891 & 6.17 & 600 \\
\hline 1\%Phosphogypsum & -1.175 & 6.21 & 400 \\
\hline
\end{tabular}

4.2 Penetration Index (PI): The penetration index, $(\mathrm{PI})$ is a measure of the temperature susceptibility of asphalt cement that can be derived mathematically from the penetration and softening point test values. Asphalt cements with penetration index (PI) above (+2) have less temperature susceptibility and are less brittle at low temperature. Large negative values of (PI) indicate greater temperature susceptibility. Typical paving asphalts have (PI) values between $(+2$ and -2$)$ which exhibits normal susceptibility to temperature. In addition, the negative sign of (PI) means that asphalt cement is more susceptible to temperature as reported by Woods et. al., [25]. As exhibited in Table 9, the penetration index of grade (6070) asphalt cement increases by (25.7 and 30.8) \% after digestion with fumed silica and Phosphogypsum respectively while it decreases by $67.2 \%$ after digestion with crumb rubber. Such behavior indicates that the temperature susceptibility of the binder increases after the addition of fumed silica and Phosphogypsum while it decreases after the addition of crumb rubber as compared to the control binder. On the other hand, similar behavior could be detected for grade (40-50) asphalt cement. The PI increases by (11.3 and 154.4) \% after digestion with fumed silica and Phosphogypsum respectively while it decreases by $15.5 \%$ after digestion with crumb rubber. Such behavior may be attributed to the high specific surface area of fumed silica and Phosphogypsum and lower specific surface area of crumb rubber powder which can restrict the possible chemical reaction with asphalt molecules. Such findings agree with Khodary, [3] work.

4.3 Penetration Viscosity Number (PVN): In this approach, the temperature susceptibility is based on penetration measurement at $25{ }^{\circ} \mathrm{C}$ and viscosity at $135{ }^{\circ} \mathrm{C}$. Higher values of (PVN) indicate lower temperature susceptibility. As indicated in Table 9, implication of crumb rubber additive exhibit in general lower PVN for both grades of binder as compared to the control asphalt cement. The PVN decreases by (5.5 and 1) \% after the addition of crumb rubber for (60$70)$ and (40-50) penetration grade binders respectively. Such behavior indicates higher temperature susceptibility. On the other hand, implication of fumed silica or Phosphogypsum exhibit no significant variation in PVN as compared to the control binder. similar findings were reported by Silva et al., [5].

4.4 Stiffness Modulus (SM): The shell nomograph, as shown in Van der Poel, [26] is applied to determine the stiffness modulus of asphalt cement based on the test temperature, the time of loading, ring and ball softening point and temperature susceptibility (penetration index) for asphalt cement. The stiffness modulus of various asphalt binder blends was determined at temperature of $60^{\circ} \mathrm{C}$, using a single loading time of 0.02 second. The time of loading is approximately 0.02 second which is related to the typical traffic speed (50 $60 \mathrm{Kph}$ ) according to Strategic Highway Research Program (SHRP) as cited by Hunter et al., [27]. Table 9 exhibit the influence of additives on the stiffness modulus of the binder. It can be noted that implication of crumb rubber increases the stiffness modulus by (33.3 and 20) \% for (60-70) and (40-50) penetration grade binders respectively. This may be attributed to the possible chemical reaction between the rubber and asphalt molecules which increases the viscosity of the binder. However, implication of fumed silica or Phosphogypsum into the asphalt binder of both penetration grades asphalt cement have reduced the stiffness modulus significantly. This could be related to the higher specific surface area of the additives.

4.5 Influence of Additives on Permanent Deformation of Asphalt Concrete: Figure 3 demonstrates the influence of additives on permanent deformation of asphalt concrete mixture prepared with (40-50) penetration grade binder. It can be noted that both crumb rubber and Phosphogypsum had a significant control on the deformation behavior of asphalt concrete while implication of fumed silica shows significant control up to 80 load repetitions, then the behavior decline, and high deformation could be observed at failure as 
compared to the control or other additives mixtures. Similar behavior was reported by Mahdi and Sarsam, [9].

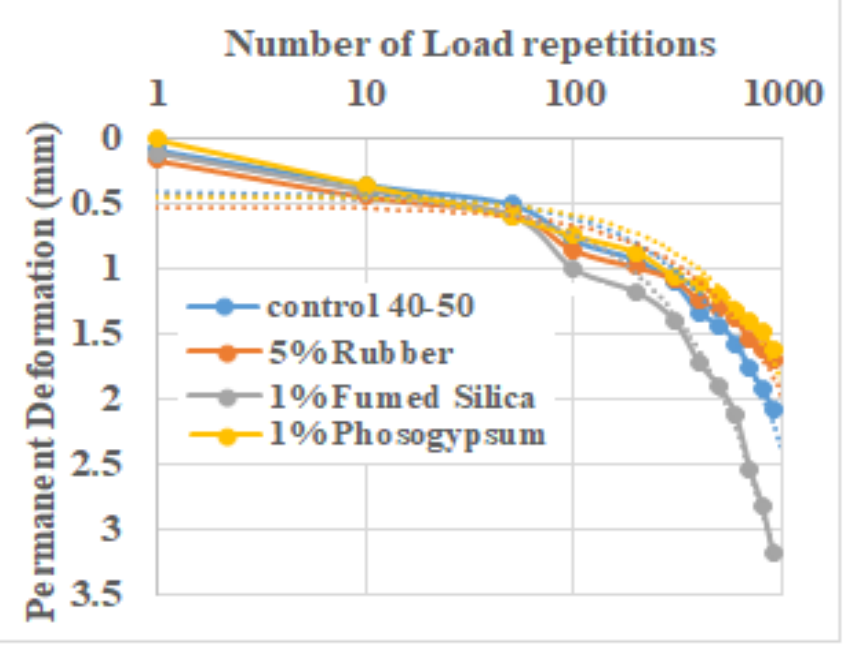

Figure 3. Influence of Additives on Deformation for (40-50) Binder

Figure 4 exhibit the influence of additives on deformation behavior of asphalt concrete prepared with (60-70) penetration grade binder. It can be observed that crumb rubber or Phosphogypsum additives implementation was able to reserve the strength and control the permanent deformation of the mixtures. Implication of fumed silica exhibit negative influence on the resistance of asphalt concrete to the permanent deformation.

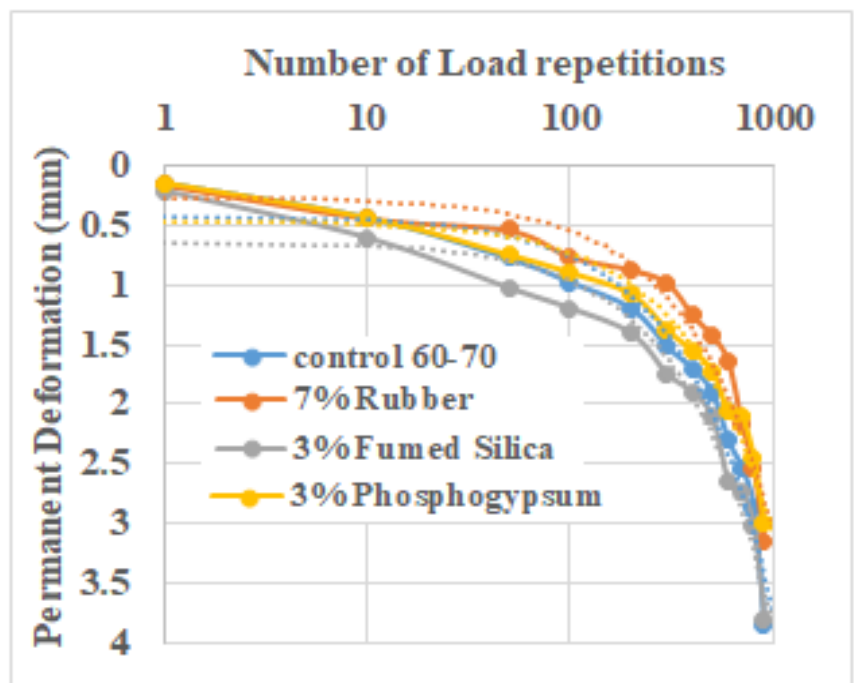

Figure 4. Influence of Additives on Deformation for (60-70) Binder

4.6 Influence of Additives on Permanent Deformation Parameters: Table 10 demonstrate the influence of binder additives on permanent deformation parameters of asphalt concrete prepared with (40-50) penetration grade binder. It can be noted that the permanent deformation after 1000 load repetitions declines by (18.2 and 22.5) \% when crumb rubber and Phosphogypsum additives were implemented respectively. This may be attributed to the higher stiffness modulus of the blend. However, the permanent deformation increases by $52.8 \%$ when fumed silica was implemented. On the other hand, the intercept which represent the deformation after the first loading repetition exhibit no significant variation (within $5 \%$ ) when fumed silica or Phosphogypsum were implemented, while the intercept increases by $27 \%$ for rubber treated mixture. The slope which represents the rate of deformation is significantly indicating the positive influence of additives in controlling the deformation process. The slope decreases by (25 and 30) \% by implication of rubber and Phosphogypsum additives respectively. Such behavior is further supported by the high stiffness modulus of the mixtures. The slope increases by $50 \%$ for mixture with fumed silica additive. Findings agrees well with (Korayem et al., [2].

Table 10. Permanent Deformation Parameters for Mixtures with (40-50) Grade Binder

\begin{tabular}{|c|c|c|c|c|c|}
\hline Mixture Type & Intercept & Slope & $\begin{array}{l}\text { Permanent } \\
\text { deformation } \\
(\mathrm{mm})\end{array}$ & Model & $\mathrm{R}^{2}$ \\
\hline Control & 0.407 & 0.002 & 2.08 & $\begin{array}{l}\mathrm{Y}= \\
0.4075 \\
+0.002 \\
\mathrm{X}\end{array}$ & 0.95 \\
\hline $5 \%$ Rubber & 0.517 & 0.001 & 1.70 & $\begin{array}{l}\mathrm{Y}= \\
0.5174 \\
+0.0015 \\
\mathrm{X}\end{array}$ & 0.90 \\
\hline $\begin{array}{ll}1 \% & \text { Fumed } \\
\text { Silica } & \end{array}$ & 0.428 & 0.003 & 3.18 & $\begin{array}{l}Y= \\
0.4283 \\
+0.003 \\
X\end{array}$ & 0.97 \\
\hline $\begin{array}{l}1 \% \\
\text { Phosphogypsum }\end{array}$ & 0.439 & 0.001 & 1.61 & $\begin{array}{l}Y= \\
0.4394 \\
+0.0014 \\
X\end{array}$ & 0.87 \\
\hline
\end{tabular}

Table 11 exhibit the influence of additives on the deformation parameters of asphalt concrete prepared with (60-70) penetration grade binder. It can be observed that the permanent deformation after 1000 load repetitions decreases after implication of the additives. The permanent deformation decreases by $(16.8,13.4$, and 20.8$) \%$ for mixtures with rubber, fumed silica, and Phosphogypsum additives respectively. This could be related to the stiffer mixtures obtained when additives were introduced. The intercept exhibits no significant variation (within $5 \%$ ) when fumed silica or Phosphogypsum were implemented, while the intercept increases by $27.5 \%$ for rubber treated mixture. The slope is significantly indicating the positive influence of additives in controlling the deformation process. The slope decreases by (15, 3 and 21$) \%$ by implication of rubber, fumed silica, and Phosphogypsum additives respectively. Such behavior is further supported by the high stiffness modulus of the mixtures. 
Table 11. Permanent Deformation Parameters for Mixtures with (60-70) Grade Binder

\begin{tabular}{|c|c|c|c|c|c|}
\hline Mixture Type & Intercept & Slope & $\begin{array}{l}\text { Permanent } \\
\text { deformation } \\
(\mathrm{mm})\end{array}$ & Model & $\mathrm{R}^{2}$ \\
\hline Control & 0.4308 & 0.0033 & 3.79 & $\begin{array}{l}\mathrm{Y}= \\
0.4308 \\
+0.0033 \\
\mathrm{X}\end{array}$ & 0.95 \\
\hline 7\% Rubber & 0.2730 & 0.0028 & 3.15 & $\begin{array}{l}\mathrm{Y}= \\
0.2730 \\
+0.0028 \\
\mathrm{X}\end{array}$ & 0.95 \\
\hline $\begin{array}{ll}3 \% & \text { Fumed } \\
\text { Silica } & \end{array}$ & 0.6432 & 0.0032 & 3.28 & $\begin{array}{l}Y= \\
0.6432 \\
+0.0032 \\
X\end{array}$ & 0.96 \\
\hline $\begin{array}{l}3 \% \\
\text { Phosphogypsum }\end{array}$ & 0.4709 & 0.0026 & 3.00 & $\begin{array}{l}\mathrm{Y}= \\
0.4709 \\
+0.0026 \\
\mathrm{X}\end{array}$ & 0.96 \\
\hline
\end{tabular}

\section{Conclusions}

Based on the limitation of materials and the testing program, the following conclusions can be drawn.

- The temperature susceptibility of the binder in terms of PI increases after digestion with fumed silica and Phosphogypsum while it decreases after the addition of crumb rubber as compared to the control binder.

- The PVN decreases by (5.5 and 1) \% after the addition of crumb rubber for (60-70) and (40-50) penetration grade binders respectively. Such behavior indicates higher temperature susceptibility.

- Implication of crumb rubber increases the stiffness modulus by (33.3 and 20) \% for (60-70) and (40-50) penetration grade binders respectively.

- The permanent deformation after 1000 load repetitions declines by (18.2 and 22.5) \% when crumb rubber and Phosphogypsum additives were implemented into (40-50) penetration grade binder respectively. However, it increases by $52.8 \%$ when fumed silica was implemented.

- The rate of deformation declines by (25 and 30) \% by implication of rubber and Phosphogypsum additives respectively for (40-50) grade binder.

- The permanent deformation decreases by (16.8, 13.4, and 20.8) \% for mixtures of (60-70) binder with rubber, fumed silica, and Phosphogypsum additives respectively.

- The rate of deformation declines by $(15,3$ and 21$)$ $\%$ for (60-70) binder by implication of rubber, fumed silica, and Phosphogypsum additives respectively.

\section{References}

1. Esmaei H. A.; Zargar A. M.; Karim M. R. Investigation on physical properties of waste cooking oil Rejuvenated bitumen binder. Construction and Building Materials, Vol. 37, 2012. P. 398-405.

2. Korayem A. H.; Ziari H., Hajiloo M., A. Moniri A. Rutting, and fatigue performance of asphalt mixtures containing amorphous carbon as filler and binder modifier. Construction and Building Materials, 188, 2018. P. 905-914.

3. Khodary F. Impact of Silica fume on the properties of Asphalt pavement base course. International Journal of Engineering Trends and Technology, 35 (10), 2016. P. 487-491.

4. Aflaki S; Tabatabaee N. Proposals for modification of Iranian bitumen to meet the climatic requirements of Iran. Construction and Building Materials, 23(6), 2009. P. 2141-2150.

5. Silva L. S.; Forte M. M.; Vignol L. D.; Cardozo N. S. Study of rheological properties of pure and polymermodified Brazilian asphalt binders. Journal of Materials Science, 39(2), 2004. P. 539- 546.

6. Deepa P.; Laad M.; Sangita Investigation on bitumen modification using nitrile butadiene rubber and lowdensity polyethylene. Romanian journal of transport infrastructure, article no. 3, Vol.9, No. 1, 2020. P. 3951. DOI: $10.2478 / \mathrm{rjti}-2020-0003$.

7. Albayati A. Mechanistic Evaluation of Lime-Modified Asphalt Concrete Mixtures. Proceedings, 7th RILEM International Conference on Cracking in Pavements, Springer Netherlands. 4: 2012. P. 921-940.

8. Al-Tameemi A.; Yu Wang Y.; Albayati A. Influence of hydrated lime on the properties and permanent deformation of the asphalt concrete layers in pavement. Romanian journal of transport infrastructure. Vol. 4, No. 1. 2015. P. 1-19. DOI: 10.1515/rjti-2015-0027.

9. Mahdi M. S. and Sarsam S. I. Influence of Additives on Permanent Deformation and Resilient Modulus of Recycled Asphalt Concrete. Journal of Engineering. Vol. 26 No. 2. 2020. P. 159-175. DOI: https://doi.org/10.31026/j.eng.2020.02.12.

10. Sarsam S. I. and Jasim S. A. Assessing the impact of polymer additives on deformation and crack healing of asphalt concrete subjected to repeated compressive stress. The International Journal of Pavement Engineering and Asphalt Technology (PEAT). Volume:19, Issue:2, December. 2018. Doi: 10.1515/ijpeat-2016-0021.

11. Ahmad M., Beddu S., Hussain S., Manan A., Itam Z. Mechanical properties of hot-mix asphalt using waste crumb rubber and phenol formaldehyde polymer. AIMS Materials Science, 6(6): 2019. P.1164-1175. Doi: 10.3934/matersci.2019.6.1164.

12. Ahmad M. and Ayob M. B. Improvement of road pavement infrastructure by using polyethylene 
terephthalate \& polypropylene. Int J Adv Mech Civil Engineering 2: 2015. P.126-134.

13. ASTM. Road and Paving Materials, Annual Book of ASTM Standards, Volume 04.03, American Society for Testing and Materials, West Conshohocken, 2015. USA.

14. SCRB/R9. General Specification for Roads and Bridges, Section R/9, Hot-Mix Asphalt Concrete Pavement, Revised Edition. State Commission of Roads and Bridges, 2003. Ministry of Housing and Construction, Republic of Iraq.

15. Sarsam S. I., and Lafta I. M. Assessing Rheological Behavior of Modified Paving Asphalt Cement. American Journal of Civil and Structural Engineering, (AJCSE), Vol. 1(3) 2014. p. 47-54, July. Sciknow Publications Ltd. USA.

16. Sarsam S. I. Improving Asphalt Cement Properties by Digestion with Nano materials. Research and Application of Material Journal, RAM, Vol.1, No.6, 2013. (P 61-64). Sciknow Publications Ltd. USA.

17. Sarsam S. I., and Lafta I. M. Impact of Asphalt Additives on Rutting Resistance of Asphalt Concrete. International Journal of Scientific Research in Knowledge, (IJSRK) Vol. 2(3), 2014. P. 151-159, February.

18. Sarsam S. and Al-Delfi K. Assessing Tensile Strength and Temperature Susceptibility of Asphalt Concrete. Applied Research Journal ARJ Vol.1, Issue, 4, 2015. P.279-287, June.

19. Dalhat M. A., Al-Adham K., Habib M. A. Recycling of different plastics in asphalt concrete. Woodhead Publishing Series in Civil and Structural Engineering, 2019. P. 287-305 https://doi.org/10.1016/B978-0-08102676-2.00013-X
20. Roque, R., Simms, R., Chen, Y., Koh, C., Lopp, G. Development of a Test Method That Will Allow Evaluation and Quantification of the Effects of Healing on Asphalt Mixture. University of Florida, Project UF00084223, Final report, 2012.

21. Sarsam S. I. Influence of ageing on temperature susceptibility of asphalt concrete. International Journal of Multidisciplinary Research and Growth Evaluation. Vol.1 $\quad$ Issue 2020. www.allmultidisciplinaryjournal.com .

22. Yoder, E. and Witczak, M. Principles of Pavement Design, John Wiley, and Sons, 1975. P .289.

23. Shell, Shell Pavement Design Manual - Asphalt Pavements and Overlays for Road Traffic. Shell International Petroleum, London, 1978.

24. Tayebali A. A., Goodrich J. L., Sousa J. B., Monismith C. L. Influence of the Rheological Properties of Modified Asphalt Binders on the Load Deformation Characteristics of the Binder-Aggregate Mixtures. Polymer Modified Asphalt Binders, ASTM STP1108, American Society for Testing and Materials, Philadelphia, 1992. P. 78.

25. Woods, K.B., Berry , D.S., and Goetz, W.H. Highway Engineering Handbook, McGraw-Hill Book Company, Inc., 1982. pp.18-21, London.

26. Van der Poel, C. A. General System Describing the Visco-Elastic Properties of Bituminous and Its Relation to Routine Test Data. Shell Bitumine Reprint No. 9. 1954. Shell Laboratorium-Koninklijike.

27. Hunter R., Self A. and Read J. (2015). The Shell Bitumen Handbook, Sixth edition. Shell International Petroleum Company Ltd. ICE Publishing. 2015. www.icevirtuallibrary.com

Biographical notes

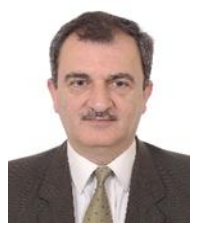

Prof. Saad Issa Sarsam was born in Baghdad (1955), got his BSc. Degree in Civil Engineering (1977); Post graduate Diploma in Transportation Engineering (1978); MSc in Transportation Engineering (1980). Worked as senior material Engineer for NCCL (National center for construction laboratories) (1982-1988); Served as Director of NCCL- Mosul, (1988-1992). Joined the academic staff at University of Mosul (1992-2005) and at University of Baghdad (2005) and got the Professor degree at (2007). Head of the Department of Civil Engineering, (20162018). Published six books and 300 research papers. Member of editorial board and reviewer of nine international scientific journals. Supervised $45 \mathrm{MSc}$ Thesis and participated in 50 national and international scientific conferences. Consultant engineer for Ministry of Industry and Military Manufacturing, FAW General Directory (1989-1990). Consultant engineer for Mosul Municipality on urban road resurfacing and construction (2001-2003). Consultant engineer for quality control on rehabilitation of Mosul International Hotel (2004). Consultant engineer for middle Euphrates international airport (2011-2013). Consultant engineer for the state company for implementation of transportation facilities, Ministry of transportation (2011-2014). Consultant engineer for NCCLR, Baghdad (2011-2015). Consultant engineer for AFM GroupSwitzerland, Baghdad international airport rehabilitation (2014). Consultant engineer for ministry of transport (2017). Director of Sarsam and Associates Consult Bureau SACB. Areas of specialization and interest (Environmental impact, Safety issues in roadway operation, Airport Engineering; Nano materials in asphalt pavement, Roller compacted concrete; Modified asphalt concrete; Asphalt stabilized embankment models; Road user characteristics). 